\title{
Coercion in Late Antiquity: a Brief Intellectual History
}

\author{
Peter Van Nuffelen
}

Don't you dream of a world, a society, with no coercion?

Yes: where a foetus is able to refuse to be born. ${ }^{.}$

\section{Introduction}

Religious violence is usually taken to encompass clashes between religious groups and the destruction these caused, as well as violence organised by institutions, in particular state and Church, against religious minorities. Using a broader definition of violence than just physical violence, ${ }^{2}$ such institutional violence included measures used to coerce individuals to abandon certain practices and beliefs judged harmful to society and themselves. This conjures up the question as to what coercion actually meant in Late Antiquity.

This chapter seeks to understand how coercion was conceptualised in Late Antiquity and to trace its origins. It is born out of discomfort with the unreflective way in which some scholarship uses concepts such as 'toleration', 'violence' and 'coercion'. 3 The uncritical usage of such terms may hamper our understanding of past societies, given the moral charge they carry in modern usage: toleration has developed into a central value of Western societies, whilst modernity is often believed to have reduced violence in society. ${ }^{4}$ Thoroughly modern ideas associated with toleration,

This chapter is a reworked version of P. Van Nuffelen, Penser la tolérance dans l'Antiquité tardive (Paris, 2018) 93-I 28 (ch. 3). The research leading to these results has received funding from the European Research Council under the European Union's Seventh Framework Programme (FP/2007-2013)/ ERC Grant Agreement no. 313I 53.

I W. H. Auden, Collected Poems (London, 1994) 299.

2 See the General Introduction, pp. ooo-oo, Chapter I by Kippenberg, pp. ooo-oo, and Chapter 6 by Bendlin, pp. ooo-oo, all this volume.

3 See the General Introduction and Chapter ro by Mayer, pp. ooo-oo, both this volume.

${ }^{4}$ Cf. J. Gray, Enlightenment's Wake: Politics and Culture at the Close of the Modern Age (London, I995); J. P. Reemtsma, Vertrauen und Gewalt: Versuch über eine besondere Konstellation der Moderne (Munich, 2009). If there is now increasing attention for the historical variation of e.g. violence and better theoretical approaches (see e.g. C. Grey, 'Shock, Horror, or Same Old Same Old? Everyday 
such as neutrality of the state, monopoly of violence or religious toleration as central to a peaceful society, have crept into analyses of late ancient coercion. ${ }^{5}$ As our concept of toleration goes hand in hand with a narrative of moral and historical progress (the peaceful modern state was enabled by the taming of religion), any past society is by definition intolerant. This is not much more than a syllogistic reasoning: it does not tell us more than was included in the premises. Obviously, we see in past societies many things we do not like from a modern perspective, but unreflective likes and dislikes may stand in the way of really understanding such societies. Indeed, it is not easy, but all the more necessary, to escape the opposition between tolerant polytheism and intolerant monotheism that has defined much of the debate concerning the ancient world. ${ }^{6}$

The way forward is to increase our awareness of how seemingly ordinary terms colour our understanding of Late Antiquity and, for this particular chapter, to understand better how coercion was conceptualised in Late Antiquity. ${ }^{7}$ Coercion, as a bad form of dealing with religious difference, is often taken to be the antinomy of persuasion that allows freedom of choice, a good way of negotiating religious difference. For example, Augustine's famous 'change of heart' regarding the role of coercion in the conversion of the Donatists, which will be an important example in this chapter, has been interpreted as his abandoning one system of thought (toleration) in favour of another one that rests on completely different principles (intolerance). Similarly, it is often stated that the Christian concept of toleration was fundamentally ambivalent and torn between an irenic and an eristic current. If the first rejected force, the second espoused it and gained the upper hand after Constantine. ${ }^{8}$

Violence in Augustine's Africa', Journal of Late Antiquity 6 [2013] 216-32), there is less reflection on the fact that our very interest in these concepts is due to a certain narrative of modernity.

See e.g. P. Athanassiadi, Vers la pensée unique: la montée de l'intolérance dans l'Antiquité tardive (Paris 20Io); H.-G. Nesselrath (ed.), Libanios: Für Religionsfreiheit, Recht und Toleranz (Tübingen, 20 I I); V. Leonard, 'The Origin of Zealous Intolerance: Paulus Orosius and Violent Religious Conflict in the Early Fifth Century', VChr 7I (2017) 26I-84.

${ }^{6}$ See esp. the General Introduction, pp. 00o-oo, and Chapter 6 by Bendlin, pp. ooo-oo, both this volume.

7 My approach is thus methodologically different from the one espoused by Mayer, this volume, pp. O०0-00, who uses a richer modern conceptual apparatus.

8 C. Schneider, 'Ursprung und Ursachen der christlichen Intoleranz', ZRGG 30 (1978) I93-2 I8; H. Drake, 'Lambs into Lions: Explaining Early Christian Intolerance', P\&P I 53 (I996) 3-36; G. G. Stroumsa, 'Tertullian on Idolatry and the Limits of Tolerance', in G. N. Stanton and G. G. Stroumsa (eds.), Tolerance and Intolerance in Early Judaism and Christianity (Cambridge, I998) 173-84; R. Forst, Toleranz im Konflikt. Geschichte, Gehalt und Gegenwart eines umstrittenen Begriffs (Frankfurt, 2004) 67-74; M. Kahlos, Forbearance and Compulsion: the Rhetoric of Religious Tolerance and Intolerance in Late Antiquity (London, 2009) 25; M. Marcos, 'Persecution, Apology, and the 
Such a representation is not satisfactory. I have argued elsewhere that every historical concept of toleration is ambivalent in the sense that it defines the limits of toleration on the basis of the principles that justify toleration. ${ }^{9}$ For example, John Locke does not extend toleration to the Catholics and atheists because in his view they fail to adhere to the principles that justify toleration for Protestant sects (respect of public authority and the values it represents). In our days, the French state forbids the wearing of the veil in the context of public office because it sees it as infringing on the principle of neutrality that it considers to be the guarantee of peaceful cohabitation of different religions. In other words, the expression of diversity is denied to protect that same diversity. As this chapter seeks to show, the role played by coercion in late ancient thought bears this principle out. Persuasion is accorded the primary role in settling religious difference, in a temporal and moral sense: debate should first be allowed a chance before other solutions are sought to the conflict. As we shall see, coercion comes into play when persuasion is rendered difficult and is justified by the same principles that underpin the primary role of persuasion. ${ }^{\text {IO }}$ These ideas are embedded in a pedagogical understanding of the role played by leaders in communities.

Besides illuminating how coercion and persuasion are part of a single system of thought, this chapter seeks to trace the origins of such ideas. I shall show that they can be found in pagan and Christian sources alike and that they represent the adoption by Christian authors of principles of classical philosophy. It is, therefore, misleading to speak of a 'Christian' concept of toleration or coercion: we are dealing with a late ancient phenomenon that receives a particular articulation in Christian circles but can be found elsewhere too. As said, I shall devote particular attention to Augustine's justification of the use of state coercion against the Donatists. It has too often been studied in isolation, leading to a perception of incoherence in his thought and to the idea that we see a particularly Christian or even Augustinian concept of coercion at work. I argue, by contrast, that his thought is fundamentally coherent and in line with late ancient ideas about persuasion and coercion.

Reflection of Religious Freedom and Religious Coercion in Early Christianity', Zeitschrift für Religionswissenschaft 20 (2012) 35-69.

9 Van Nuffelen, Penser la tolérance, 93-95.

ro P. Van Nuffelen, 'The End of Competition? Religious Disputations in Late Antiquity', in D. Engels and P. Van Nuffelen (eds.), Competition and Religion in Antiquity (Brussels, 20I4) I 49-72. 


\section{A Late Ancient Concept of Coercion}

Let us start by brotherly juxtaposing a Neoplatonist philosopher and a Christian bishop. In the 340 or or 350 s, the philosopher Sopater composed a letter of advice addressed to a certain Himerius who was about to become provincial governor. ${ }^{\text {II }}$ One of the extracts preserved in the anthology of Stobaeus states the following:

You must deter them from wrongdoing by joining persuasion to compulsion. To those who have gone astray, you must apply the appropriate corrective of justice. Pretend to ignore slight and common wrongdoings - for it is not helpful simply to attack everyone and anyone who comes along nor is it to overlook things when you become aware of them. Treat anything actually serious for the ruled with the remedies given by the laws. ${ }^{{ }^{2}}$

In governing his subjects, so Sopater advises, Himerius should apply both coercion and persuasion with the aim of bringing them on to the right track. Punishment is not retributive but corrective: as the medicinal metaphor of the last sentence shows, the aim is to heal the subject. The advice fits well with what we know of Neoplatonic political thought, ${ }^{\mathrm{I}}{ }^{3}$ but has also striking similarities with what, more than half a century later, Augustine said at the Conference of Carthage (4II), during which Catholic and Donatist bishops debated their disagreement:

For we say that ecclesiastical discipline is not to be neglected and, wherever evil ones have been found out, they have to be coerced so that they be corrected, not just by verbal reprimands, but also by excommunication and degradation, so that they seek a humble place of salvation in the Church. This we say to happen for their health, not by hatred but by zeal for the salvation of our brothers ... ${ }^{\text {I4 }}$

Cf. S. C. R. Swain, Themistius, Julian and Greek Political Theory under Rome: Texts, Translations, and Studies of Four Key Works (Cambridge, 2013) I7-18.

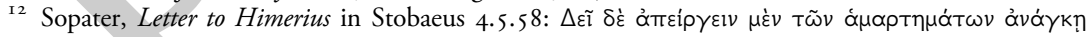

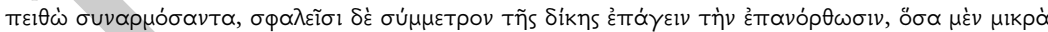

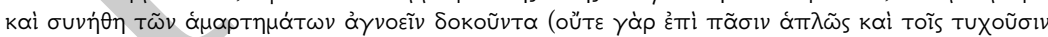

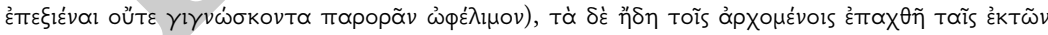

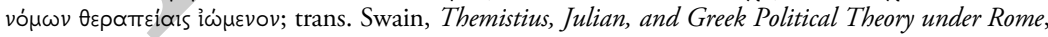
I30. See also Stobaeus 4.5.54, 56, 60; Julian, Epistulae 89в.289b (p. I56 Bidez), and II4 (pp. 193-95 Bidez, with a similar statement on Christian bishops).

${ }^{13}$ D. J. O’Meara, Platonopolis: Platonic Political Philosophy in Late Antiquity (Oxford, 2003); D. O'Meara and J. Schamp, Miroirs de princes de l'empire romain au IVe siècle (Fribourg, 2006).

${ }^{14}$ Gesta collationis Carthaginensis 3.28 I (SC I95, pp. I239-40): Dicimus enim nos non neglegendam quidem ecclesiasticam disciplinam et, ubicumque fuerint proditi mali, coercendos eos esse ut corrigantur, non solum sermone correptionis, verum etiam excommunicationibus $\langle e t\rangle$ degradationibus, ut humilem locum salutis in ecclesia quaerant. <quod dicimus $>$ ad medicinam ipsorum fieri, non odio sed studio 
Just as Himerius was to take care of the community entrusted to him (the inhabitants of the province), Augustine talks about the members of the Christian community headed by a bishop. He has to ensure that all the members of his flock are on the right track, which in this particular case means that they should not heed Donatist teachings. Augustine too uses the metaphor of medicine, showing that the aim must be to re-establish good attitudes. In this statement, Augustine lists the measures a bishop can take to correct deviants in his community: a verbal reprimand, exclusion from the community $^{\mathrm{I}}$ and degradation (this last measure can only apply to clergy). Yet these serve, as much as the measures suggested by Sopater, the creation of a good community. That is why Augustine emphasises that one can punish only out of care and not out of hatred: if one merely wishes to exact revenge for the offence or to please one's sadism, the punishment misses its aim and will be detrimental to the individual and the community, which is built on mutual love. ${ }^{16}$ In this way, Augustine traces, as much as does Sopater, a distinction between justified and unjustified measures of coercion: punishment that does not serve the good of the community is to be avoided.

It is not difficult to notice the similarity of views in these two extracts: coercion takes place within a community with the aim of keeping it healthy; to that end, coercion is corrective and must be applied with the aim of allowing the return of the offender into the community; therefore the community's leader must apply coercion with the good in mind; coercion is handed out on the basis of laws (of the state or the Church). In what follows I shall add some flesh to these bones by tracing the origins of these ideas in classical philosophy. Further evidence will help us to see better how coercion is articulated on persuasion, which has, as said, moral and logical priority over coercion.

\section{A Brief Intellectual History}

This section offers a brief sketch of the origins of the ideas we encountered in the previous section. Admittedly done with the broadest of brushes, it

salutis fraternae ...; unless indicated, as in n. I 2 above, translations throughout this chapter are mine. For background, see J. Rist, Augustine: Ancient Thought Baptized (Cambridge 1995), 244; T. J. van Bavel, 'Correctio' and 'Correptio', in C. Meyer (ed.), Augustinus-Lexicon, vol. II (Basel, 1996) 22-26 and 35-39; V. Grossi, 'Correctio', in A. Fitzgerald (ed.), Augustine through the Ages (Grand Rapids, I999) 242-44.

Is J. Hillner, Prison, Punishment and Penance in Late Antiquity (Cambridge, 2015) 70, notes that excommunication is rare as a punishment.

${ }^{16}$ On love, see D. X. Burt, Friendship and Society: an Introduction to Augustine's Practical Philosophy (Grand Rapids, I999) 217. 
addresses two questions. First, to what degree are there similarities between classical philosophy and late ancient thought, particularly Christian, regarding coercion? And second, can we consider this to be continuity of ideas and not just similarity of views?

One does not need to be widely read in ancient philosophy to note similarities between Augustine's idea of correction and classical accounts. Indeed, Michael Erler has listed a series of parallels, for example in Seneca. ${ }^{17} \mathrm{He}$ argues that Augustine differs from classical philosophy by accepting forms of violent correction (that is, coercion). At first sight, this seems logical: an apprentice philosopher entered of his own will into a philosophical community and could simply leave it were he to be subjected to coercion. Moreover, education in philosophy is a development of one's rational faculties and a basic presupposition was that one cannot be forced to be rational. One espouses the truth freely once one has understood it. Yet Augustine would agree with this last proposition: he accepted the general presupposition of Patristic thought that one cannot force someone to accept Christianity. Indeed, conversion has to be a free process, for one cannot involuntarily assent to the truth. ${ }^{\text {I }}$ This similarity suggests we should look again at this supposed difference between classical and Christian thought. In fact, there is fundamental continuity, also in the advocacy of violent coercion. One should, however, take into account the type of community that is being discussed. Indeed, philosophers made a distinction between a community of philosophers and a political community. If in the former coercion has no place, this was not the case for the latter. Indeed, the Neoplatonist philosopher Olympiodorus (c. 495-570) defined the difference between the two communities as that between persuasion, exercised by a teacher, and coercion, exercised by a political leader. ${ }^{\text {I9 }}$

Pierre Hadot has famously shown that ancient philosophy was not just a technical discipline that sought to understand man and world, but proposed a way of life that was entirely oriented towards the good (however it was conceptualised). Being a philosopher affected not just one's rational faculties, but also domains we would call spiritual and ethical. The happy life could not be reached without a rational understanding of causes and principles, which had to be freely understood, for one cannot be coerced to

${ }^{17}$ M. Erler, 'Paideia, Peitho und Bia', in C. P. Mayer and G. Förster (eds.), Augustinus - Recht und Gewalt: Beiträge des V. Würzburger Augustinus-Studientages am I5./I6. Juni 2007 (Würzburg, 2010) I3-28. Cf. Seneca, Letter 25.I-3, 52.2-6, 95.36, and De beneficiis 5.25.5.

${ }^{18}$ See e.g. Tertullian, Ad Scapulam 2.I-2 (CCSL 2, p. I I30); Lactantius, Divinae institutiones 5.2 (CSEL i 9, pp. 403-06).

19 Olympiodorus, Commentary on the Gorgias of Plato 4I.3. Cf. Plotinus, Enneads I.2.I. 
understand something. What is not fully interiorised, is not understood. ${ }^{20}$ Philosophers were aware of the difficulties that progress towards eudaimonia and knowledge posed: most people do not arrive there, even among those who really try to. Different reasons were put forward by different schools, such as a lack of knowledge (Plato), a failed control of emotions (Stoicism) or a dysfunctional will (Augustine). Generally, two types of therapy were envisaged: one that worked from the inside towards the outside, by rational argumentation; and one that worked from the outside to the inside, whereby one first adjusted one's habits, creating a good disposition in the person towards accepting the truth. The first/secondcentury Platonist Plutarch calls this epilogismos ('reflection') and ethismos ('habituation'). ${ }^{2 \mathrm{I}}$ The first form of therapy is well illustrated by Philodemus' treatise on parrhesia ('outspokenness'; first century BC). The term designates the criticism that friends exercise on each other and teachers on pupils in order to help them to progress towards virtue. Philodemus is aware that such criticism may be difficult to stomach, for example when it comes from one's social inferior, and that it may take a while before good advice is interiorised. ${ }^{22}$ Criticism here serves to change one's mind so as to entail a change in action. The second can be illustrated by Aristotle's view that one becomes virtuous by acting virtuously: that is, one needs to learn good habits, on which one reflects, in order to lift oneself from an unreflective level to a philosophical one. This will help one to interiorise the correct disposition. For Aristotle, emotions such as fear or shame can be helpful to steer one in the right direction. ${ }^{23}$ This second form of therapy helps us to see that one should not ascribe to ancient thought a purely intellectualist position, as if one first has to understand the truth or the good in order to do it.

If one compares Augustine's view on coercion with the statements of ancient philosophers uttered in relation to the philosophical community, Erler is right in noting a fundamental difference. One will not encounter

${ }^{20}$ P. Hadot, Qu'est-ce que la philosophie antique? (Paris, 1996). See e.g. Plato, Republic 4I Id, 536d6Ioc; Laws 722b; Timaeus 48a.

${ }^{21}$ Cf. G. Roskam, On the Path to Virtue: the Stoic Doctrine of Moral Progress and its Reception in (Middle-)Platonism (Leuven, 2005); L. van Hoof, Plutarch's Practical Ethics: the Social Dynamics of Philosophy (Oxford, 2010).

22 Philodemus, On Outspokenness fr. 65-67, 69. In general, see P. Lain-Entralgo, The Therapy of the Word in Classical Antiquity (New Haven, 1970).

${ }^{23}$ Aristotle, Nicomachaean Ethics I.9 I099b, 2.I I I03a-b, 6.1 3 I I 44b, I0.9 I I 80a; Eudemian Ethics I.I I2 I4a, 2.2 I220a-b; Politics 8. I I337a. Cf. Z. Hitz, 'Aristotle on Law and Moral Education', Oxford Studies in Ancient Philosophy 42 (2012) 263-306. For parallel ideas in Seneca, see N. Sherman, 'Of Manners and Morals', British Journal of Educational Studies 53 (2005) 272-89. 
the use of force in a philosopher's reflection on progress in such a community. Yet ancient philosophers also envisaged a different community, that of the city. In philosophical thought, the political community was also understood as a community oriented towards the good, in which each individual aspired to living a virtuous life and helped in rendering the entire community virtuous. If a community of philosophers consisted of people willing to become virtuous, this was hardly the case for all citizens. Moreover, if achieving eudaimonia was hard for philosophers, it was so much more for ordinary individuals. The central question of ancient political thought is, therefore, 'How can a city be virtuous?' Xenocrates, the successor of Plato at the helm of the Academy (c. 400-3 I4 B CE), saw no other option but coercion:

[They] confirmed the remark of Xenocrates about true philosophers, that they alone do willingly what all others do unwillingly because of the law, even as dogs by a blow and cats by a noise are turned from their pleasures and regard with suspicion the danger that threatens them. ${ }^{24}$

Coercion, through positive law, helps to bring about a virtuous community. From a different angle, Aristotle considered good laws necessary to bring about a good initial disposition in young people that would help them to open up to the counsel of reason. He did not spell out if he thought this would be enough to bring about moral excellence in all individuals. Even so, Aristotle did not believe in an easy path to virtue: 'Moral learning is more a matter of constraint and discipline than of skipping freely towards the delights of virtue. ${ }^{25}$ In his Laws, Plato seems to have envisaged the necessity of tyrannical rule by the so-called young tyrant in order to make a community progress towards virtue. Significantly, this tyrant was supposed to use both persuasion and coercion. ${ }^{26} \mathrm{His}$ rule would be a provisional stage in the creation of a virtuous community, but the Laws make clear that persuasion and coercion always remain linked. Indeed, the laws that Plato draws up in this dialogue are preceded

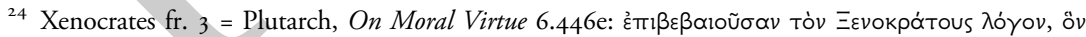

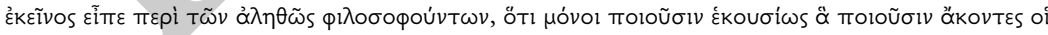

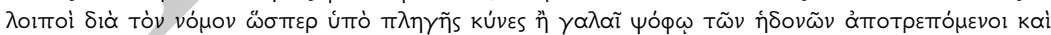

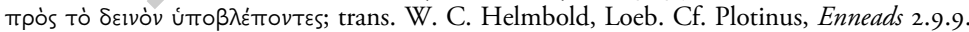

25 Aristotle, Nicomachaean Ethics I I79b. I 5. Quotation from Hitz, 'Aristotle on Law', 294. See also H. J. Curzer, 'Aristotle's Painful Path to Virtue', JHPh 40 (2002) I 4I-62.

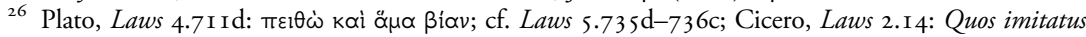
Plato videlicet hoc quoque legis putavit esse, persuadere aliquid, non omnia vi ac minis cogere. M. Schofield, Plato (Oxford, 2006) 43-50, dismisses the role of the young tyrant as irony, but see L. Brisson, 'Le tyran dans les lois: la violence fondatrice', in S. Gastaldi and J.-F. Pradeau (eds.), Le philosophe, le roi, le tyran (Sankt-Augustin, 2009) I29-37, esp. p. I34. 
by extensive and moralising preambles. As argued by André Laks, they ensure that the ideal state as sketched in the Laws is not reduced to the mere exercise of legal violence. Naked laws without preambles that seek to convince the subjects would run counter to the fundamental aim of creating a virtuous community: indeed, one can only accept the truth voluntarily and not through coercion. Even so, many people will not be able to rise to that level, rendering laws and coercion necessary to ensure that the community as a whole is virtuous (and hence a real community, for a community without the order of virtue cannot continue to exist). ${ }^{27}$ In ancient philosophy, then, the political community cannot survive without laws, which, on the one hand, create good dispositions in the individuals that can rise to the level of true virtue, and, on the other, ensure that the community as a whole, including its weakest members, remains virtuous. As Plato's Laws illustrate, coercion remains embedded in a wider belief in the logical and moral priority of rational persuasion.

In Late Antiquity, one finds similar conceptions among Neoplatonist thinkers. In his commentary on the Gorgias of Plato, Olympiodorus starts out from the idea that we are all in need of re-education, for we all make errors. The political leader has to do this for the civic community - a process that Olympiodorus compares to the taming of wild horses. Another comparison is a teacher, except that Olympiodorus concedes that the political leader has a wider arsenal of tools. His primary means is rational persuasion, but Olympiodorus also accepts the use of tribunals and the application of punishments, including the death sentence. Yet a fundamental condition of such actions by the leader is that he himself is just - just as Augustine demanded that coercion should be done for the good of community and not out of personal hatred. ${ }^{28}$

If, then, we look at how ancient philosophers thought about moral progress in both communities, philosophical and political, one has to accept the fundamental identity of views between Sopater, whom we tend to see as an inheritor of classical thought, and Augustine, whom we would label an exponent of Christian thought. By 'fundamental identity' I mean that the formulations may differ but the underlying frame of thought is identical. In this respect I differ from the important account of ancient and Christian discourses on punishment recently offered by Julia Hillner. Whilst recognising the similarity between Christian views and those of

\footnotetext{
27 A. Laks, Médiation et coercition: pour une lecture des Lois de Platon (Villeneuve d'Ascq, 2005). Schofield, Plato, 84-88 downplays the importance of coercion.

${ }^{28}$ Olympiodorus, Commentary on the Gorgias of Plato 41.2-45.2.
} 
Plato, Hillner sees a difference in result between Christian penance and secular attitudes: in Christian thought, 'penance did not return a human soul to virtue or wipe out sinfulness, but gave individuals a second chance at equipping themselves for facing the final judge of their sinfulness' (that is, God in the Final Judgement). ${ }^{29}$ Yet, I would argue, penance and other forms of disciplining within the Church were also about social reintegration and not just about individual salvation: indeed, the Church was considered to be the community to which one should belong in order to hope for salvation. Hillner seems, in fact, to ignore the ecclesiological dimension of Patristic thought. Hence, as in the quotation of Augustine above, individual salvation and communal integrity go hand in hand..$^{30}$

I shall answer my second question (Does this similarity betray continuity of thought?) more rapidly, also by engaging with Hillner's account. She has admirably traced how in Late Antiquity reform came to dominate the discourse on punishment. This marks a change from early imperial legal thought, she argues, when most justifications 'remained focussed on retribution, deterrence, and the preservation of honour which had always characterised Roman punishment'. ${ }^{\text {I }}$ By Late Antiquity, emphasis was put on the reform of the offender, generating the curative metaphors we encountered earlier: even serious offenders were now considered to be able to amend their ways. She also notes, as has Jill Harries before, the interesting similarities between the preambles of late ancient laws and Plato's own laws and more generally between this discourse on reform and Plato's thought. ${ }^{32}$ Much more than earlier periods, late ancient thought considered punishment and the legal system to be educative. In this evolution, Hillner attributes a prime role to Christianity, which 'shifted the focus onto the offender'. ${ }^{33}$ Even if she may be right in seeing Christianity as the main conduit for transmitting Platonic ideas (at least it is the Christian discourse that our sources transmit predominantly), a

29 Hillner, Prison, 73. See also V. Neri, 'I cristiani e la giustizia penale: principi e prassi (sec. IV-V)', in C. Freu, S. Janniard and A. Ripoll (eds.), Libera curiositas: mélanges d'histoire romaine et d'Antiquité tardive offerts à Jean-Michel Carrié (Turnhout, 2016) 369-86.

30 Augustine, De civitate Dei 2 I. I I (CCSL 48, pp. 777-78) does differentiate the Christian position from the Platonic one, stating that Platonists believe that punishment after this life is also educative. He alludes to the belief of Platonists in the continued improvement of the soul after the death of the body, leading to its return to the divine. This is, in fact, a difference in anthropology (Christians do not believe that souls transmigrate or continue their journey), not in underlying conception of punishment.

3 I Hillner, Prison, 63.

32 J. Harries, 'Superfluous Verbiage? Rhetoric and Law in the Age of Constantine and Julian', JECS I9 (20 I I) 345-74; Hillner, Prison, 28-37, 94.

${ }^{33}$ Hillner, Prison, I 4. 
striking absence in her account is Neoplatonic accounts: indeed, we encounter very similar views in the Neoplatonist pagans Sopater and Olympiodorus. Unless one wishes to believe that Neoplatonism was influenced by Christianity or that we see the accidental confluence of two separate traditions (Hellenism and Christianity), this suggests that the rise of the discourse of reform is linked to the rise of Platonism as the philosophical koine of Late Antiquity, a koine to which Christianity was also tributary.

Thus, Sopater and Augustine think alike not because they have reached the same summit by different routes, but because they partake in the same culture and intellectual tradition. The preceding pages have also shown something else: coercion is always conceptualised in relation to persuasion. Rational argument is the only means by which one can accept the truth and coercion can never be a substitute for it. Coercion enters the picture when argument is problematic, but even Plato's 'young tyrant' uses force and persuasion. Coercion, then, was not a problem in ancient thought: a real political community was always considered to apply a degree of coercion because individuals always fall short of the ideal. With this in mind, we can now turn to Augustine's justification of coercion. As we shall see, he did not change his views in the fundamental way sometimes asserted, nor is the issue at stake the justification of coercion as such. It is the source of coercion that is problematic.

\section{Augustine on Coercion by the State}

Early in the fifth century, Augustine justified the use of imperial legislation to force the Donatists into a return to the Catholic Church. By this time, the conflict between both groups had been dragging on for almost a century, having started with the disputed election of Caecilianus as bishop of Carthage in $3 \mathrm{II} / \mathrm{I} 2$. The memory of past violence, kept alive by both sides, led to a poisoned climate. Faced with the violence perpetrated by the so-called circumcelliones, the Catholic episcopacy seems to have split between two options. A strict position seems to have been defended by the bishops living inland where violence was most intense. They demanded general imperial intervention against the Donatists. Bishops located on the coast, where violence was rare, seem to have advocated a reliance on persuasion and on limited measures against Donatist bishops judged responsible for the violence. In 405, Maximinus of Bagai arrived at the court of Ravenna, apparently on his own initiative. Having been beaten up by the Donatists himself, his story made a great impression 
and a series of severe measures were decreed, in particular high fines and the confiscation of property threatened Donatists. ${ }^{34}$ Although imperial policy was far from consistent in the years to come, these measures can be seen as the starting point of a process that would lead to the final victory of the Catholic Church, with the culmination in the Conference of Carthage of $4 \mathrm{II}$.

The conflicting views in the African episcopate are best known through the correspondence of Augustine, who defended the anti-Donatist measures most elaborately in a letter to the Rogatist Bishop Vicentius (belonging to a Donatist faction) (Letter 93 [408]) and one to the military commander Boniface (Letter I85 [4I7]). He states explicitly that he was originally opposed to the use of imperial coercion: 'For I thought at first that no one can be forced to be united to Christ and that one had to act by words. ${ }^{35}$ This confessed change of heart, to which he also admits in his Retractationes, ${ }^{36}$ has been judged severely in older scholarship. His desire to see Donatism disappear would have led him to a fundamental contradiction with his earlier doubts about the Roman state and introduced a fundamental incoherence in his own thought. ${ }^{37}$ Worse still, as extracts of the letters were inserted into the Decretum Gratianum, the compilation of canon law of II40, Augustine has even been called Father of the Inquisition - a more damming condemnation is hardly imaginable to a modern mind..$^{38}$ Such a judgement, as well as the feeling that these letters are a blot on Augustine's reputation, betray that his argument hurts our modern sensibilities: our appropriation of Augustine as a maître à penser for all ages reaches a painful limit. ${ }^{39}$ Scholarship has added important

34 Codex Theodosianus 16.5.38, I6.II.2, with C. Weidemann, 'Eine Intrige im katholischen Episkopat? Zum Anlass der antidonatistischen Gesetze von 405', in G. Förster et al. (eds.), Spiritus et littera: Festschrift zum 80. Geburtstag von Cornelius Petrus Mayer OSA (Würzburg, 2009) 39I-403; B. D. Shaw, Sacred Violence: African Christians and Sectarian Hatred in the Age of Augustine (Cambridge, 20II) 474-84.

35 Augustine, Epistulae 93.5.17 (CSEL 34.2, p. 46I): Nam mea primitus sententia non erat nisi neminem ad unitatem Christi esse cogendum verbo esse agendum.

${ }^{36}$ Augustine, Retractationes I.I3.6 (CCSL 57, pp. 38-39).

37 G. O. Willis, Augustine and the Donatist Controversy (London, 1950) I 27-35; H. A. Deane, The Political and Social Ideas of St Augustine (New York, I963) 216-19; E. Lamirande, Church, State and Toleration: an Intriguing Change of Mind in Augustine (Villanova, 1975).

${ }^{38}$ References in Lamirande, Church, 70; P. van Geest, 'Timor est servus caritatis (S. I 56.13-14): Augustine's Vision on Coercion in the Process of Returning Heretics to the Catholic Church and his Underlying Principles', in A. Dupont, M. A. Gaumer and M. Lamberigts (eds.), The Uniquely African Controversy: Studies on Donatist Christianity (Leuven, 2015) 289-31 10, esp. p. 289 (n. I).

39 That it is seen as a stain on his reputation becomes clear from the defensive tone of recent papers by P. van Geest, 'Quid dicam de vindicando vel non vindicando? (Ep. 95, 3): Augustine's Legitimation of Coercion in the Light of his Roles of Mediator, Judge, Teacher and Mystagogue', in A. C. Geljon 
nuance to such judgements. The situational character of the justification has been emphasised, leading to a view of Augustine, in this respect, as a 'pragmatic prelate' pursuing a pastoral strategy rather than a coherent thought. ${ }^{40}$ Parallels with other texts have been highlighted, showing that Augustine held such ideas on coercion already in the $3905-$ which implies that his change of heart was less abrupt than it may seem. ${ }^{4 \mathrm{I}}$ Even if much scholarship still tends to assume a change of $\operatorname{mind},{ }^{42}$ it has laid the groundwork for ascribing a greater coherence to Augustine's views than is usually accepted. ${ }^{43}$ In fact, if we abandon the modern presupposition that coercion and rational argument are two mutually exclusive attitudes to religious difference, we are able to see that Augustine remains within the late ancient frame of thought as sketched in the first half of this chapter and to understand why the problem triggering the letters is not coercion itself but coercion by the state. This obviously does not mean that Augustine may not have changed his mind as to what was the best way to solve the Donatist problem, but this is not a change affecting the basic frame of thought - the deeper level with which I am concerned here.

The letters make abundantly clear that persuasion has logical, if not temporal priority over coercion. In fact, Augustine's confession of a change of heart rhetorically draws attention to the fact that his underlying position is still the same, namely that persuasion is the only real tool to bring about conversion: 'If they [the Donatists] were to be terrified and not instructed, that would seem an immoral tyranny. ${ }^{44}$ Instruction here indicates the use of rational argument showing that the Catholic position is the right one.

and R. Roukema (eds.), Violence in Ancient Christianity: Victims and Perpetrators (Leiden, 2014) I 5 I-84, and 'Timor est servus caritatis'.

$4^{\circ}$ F. H. Russell, 'Persuading the Donatists: Augustine's Coercion by Words', in W. E. Klingshirn and M. Vessey (eds.), The Limits of Ancient Christianity: Essays on Late Antique Thought and Culture in Honor of R.A. Markus (Ann Arbor, I999) i I 5-30, esp. p. I29. See also Van Geest, 'Quid dicam de vindicando'. Russell takes inspiration from R. A. Markus, Saeculum: History and Society in the Theology of Saint Augustine (Cambridge, 1970) I 32-53. P. Brown, Augustine of Hippo: a Biography, 2nd ed. (London, 2000) 227, states that Augustine, as leader of a minority community faced with a Donatist majority, could not afford tolerance. This posits (modern) toleration as the normal attitude.

${ }^{41}$ P. Brown, 'Religious Coercion in the Later Roman Empire', repr. in his Religion and Society in the Age of Saint Augustine (London, I972) 30 I-3 I; G. Clark, 'Rod, Line and Net: Augustine on the Limits of Diversity', Studies in Church History 43 (2001) 80-99; Van Geest, 'Quid dicam de vindicando' and 'Timor est servus caritatis'.

${ }^{42}$ Most recently, Van Geest, 'Quid dicam de vindicando', I60; M. A. Gaumer and A. Dupont, 'Donatist North Africa and the Beginning of Religious Coercion by Christians: a New Analysis', La Ciudad de Dios 223 (2010) 445-66.

43 See already Markus, Saeculum, I 32-53.

${ }_{44}$ Augustine, Epistulae 93.I.3 (CSEL 34.2, p. 448): si enim terrerentur et non docerentur, inproba quasi dominatio uideretur. 
Coercion without subsequent argument would suffer from the same weakness as when Plato added no preambles to his laws: the Donatists would have to submit to naked power without being able to rationally understand the correctness of the Catholic position. Power only touches the exterior of humans, whereas true conversion hinges on the free and rational acceptance of the truth. As Augustine says aphoristically in $D e$ catechizandis rudibus, 'faith is not a matter of a dancing body but of a believing soul'. 45

If coercion remains embedded in a system of thought that attributes priority to persuasion and indeed underlines its necessity, why then accept the use of force? Augustine offers two reasons in the passage following the one I have just cited. First, 'if they were to be instructed and not terrified, they would move more slowly on to the road of salvation, obdurate by the long-term power of habit'. As we have seen above, bad habits were also singled out by philosophers as a barrier to rational argument. Second, 'the fear for the violent hostilities of evil men' (that is, the circumcelliones) renders the Donatists reluctant to join the Catholic Church, for, if they do, they fear retaliation. ${ }^{46}$ This last factor is specific for Augustine's argumentation: in his view, Donatist violence has eliminated the mere possibility of starting a discussion and of letting persuasion work. Both reasons given by Augustine point to a common assumption about the role of coercion: it seeks to remove barriers to persuasion. Coercion is not an aim in itself, in line with what Augustine said in the first quotation from his works in this chapter ${ }^{47}$ but only prepares the ground for persuasion. The forced entry of Donatists into the Church is therefore an occasion to teach them the truth, in line with the general medical or pedagogical understanding of the process. ${ }^{48}$ As in the earlier quotation, and in line with philosophical thought, Augustine emphasises that its exercise is limited by the

Augustine, De catechizandis rudibus I I.16.5-9 (CCSL 46, p. I40): fides enim non res est saltantis corporis, sed credentis animi.

${ }^{46}$ Augustine, Epistulae 93.I.3 (CSEL 34.2, p. 448): si enim terrerentur et non docerentur, inproba quasi dominatio uideretur. rursus si docerentur et non terrerentur, uetustate consuetudinis obdurati ad capessendam uiam salutis pigrius mouerentur, quando quidem multi, quod bene nouimus, reddita sibi ratione et manifestata diuinis testimoniis ueritate respondebant nobis cupere se in ecclesiae catholicae communionem transire, sed uiolentas perditorum hominum inimicitias formidare, quas quidem pro iustitia et pro aeterna uita utique contemnere debuerunt; sed talium infirmitas, donec firmi efficiantur, sustinenda est, non desperanda.

47 See above, p. ooo.

${ }^{8}$ A point underscored by Russell, 'Persuading the Donatists'; Clark, 'Rod, Line and Net'; Van Geest, 'Quid dicam de vindicando', I70, and 'Timor est servus caritatis', 320; E. Smither, 'Augustine, Missionary to Heretics? An Appraisal of Augustine's Missional Engagement with the Donatists', in Dupont et al., Uniquely African Controversy, 269-88. 
correctness of the intentions of the one applying the coercion and by the fact that it must be oriented towards the truth. ${ }^{49}$ The use of 'truth' may run counter to modern presuppositions, according to which religious views have been banned to the realm of the rationally unjustifiable ('beliefs' or 'faith' rather than 'truth'). Yet, in Antiquity, theology was a branch of philosophy and the subject of rational argument and justification. By Late Antiquity, one would not be wrong to state, theology was the locus of reason.

If Augustine's position is in line with general thought of the period and his own earlier positions, why did he then seek to provide ample justification for it? There is, obviously, the fact that the Donatists too claimed to possess the truth, necessitating a demonstration that the Catholic position is the correct one. Yet Augustine does not spend much time on setting out his theological stall, and rather deals with other objections. He addresses the problem of the so-called ficti, that is, individuals who pretended to be Catholics but were not. Indeed, if one forces the Donatists to enter the Catholic Church, they do not become Catholics overnight. They only pretend to be so, possibly for a long time. Yet ficti were not a problem for a community, for it always contained such individuals. In De catechizandis rudibus, Augustine accepts the permanent presence of ficti in a Christian community, because people may convert because of dishonest reasons, such as social advancement (for example, to seek a career in imperial administration) or social pressure (to marry a Christian wife). The preacher has to purify their heart and make them progress to the truth. This is hard work that may take a long time, for the seed sown may take a while to grow. Donatist ficti are, then, at best a problem of degree: if they were a large group or even the majority of a community, instruction would become very difficult. Augustine counters this problem with two clarifications. First, he alleges a great success in conversion among the Donatists who have been forced to enter. Especially since the clear defeat for the Donatists at the Conference of Carthage (4I I), so he claims, spontaneous and sincere conversion has taken place. Second, the problem of ficti is the price to pay to stop a much greater evil, namely the unbearable violence against the Catholics and Donatists who wish to convert to Catholicism. ${ }^{50}$

The real problem addressed by Augustine's so-called justification of coercion is not coercion itself, which was acceptable as long as it was

\footnotetext{
49 Augustine, Epistulae 93.2, 93.5.I6 (CSEL 34.2, pp. 448-53, 46I), I 85.1 I.5 I (CSEL 57, p. 44).

so Augustine, Epistulae 93.13 (CSEL 34.2, pp. 494-96); Epistulae I 85.7.30 (CSEL 57, p. 28); De catechizandis rudibus I I.I6.5-9 (CCSL 46, p. I40).
} 
exercised by the leader of the community and embedded in a wellintentioned pedagogical process, nor was it the creation of ficti. Rather, it is the recourse to imperial power to solve a conflict internal to the Christian community. ${ }^{5 \mathrm{I}}$ In the two letters of Augustine that we are discussing, we encounter several objections that touch precisely on this issue. First, Donatists object that 'no example can be found in the Gospels or in the apostolic letters that something was asked for the Church from the earthly kings against the enemies of the Church'. Augustine responds: 'who denies that it cannot be found? But then this prophecy had not yet been fulfilled: "and now, kings, understand and be instructed, you who judge the earth. Serve the lord in fear" (Psalm 2:10). ${ }^{52}$ For Augustine, it would have been unjustified to demand help from a pagan emperor, but because the world is becoming Christian, there are now Christian rulers. Augustine also tackles the Donatist objection in a less theological way: they too have demanded help from the rulers, and it is therefore hypocritical to claim that it is illegitimate if the Catholics do so. ${ }^{53}$ Second, he underlines the fact that the imperial measures aim at correction and not punishment, and that they are therefore moderate in nature. He contrasts the antiDonatist laws, which foresee fines and exile as punishment, with antipagan measures, which contain the death penalty. Their clemency, so Augustine says, has the aim of making the Donatists reflect on the reasons why they suffer such penalties and hence on the propaganda of their own camp. Indeed, because of the violence and the lies that have long circulated, it has become illusory to believe that the normal mechanism of debate and argument would be able to reunite both communities: habit is now too strong. ${ }^{54} \mathrm{We}$ encountered the motive of fear as a healthy emotion that can lead to the breaking of bad habits already in classical philosophy.

Augustine, then, suggests that the confluence between Church and state, due to the presence of Christian rulers, allows, exceptionally, the use of imperial coercion. This exception is due to the violence of the circumcelliones that disrupts the normal mechanism of persuasion and prevents it working. In that way, imperial coercion is seen to function in the same way as coercion applied by the leader of the community himself (that is, the bishop), yet it is needed given the exceptional circumstances.

\footnotetext{
51 Van Geest, 'Quid dicam de vindicando', I 53; Hillner, Prison, 78-80.

52 Augustine, Epistulae 93.3.9 (CSEL 34.2, p. 453): non inuenitur exemplum in euangelicis et apostolicis litteris aliquid petitum a regibus terrae pro ecclesia contra inimicos ecclesiae. quis negat non inueniri? sed nondum implebatur illa prophetia: et nunc, reges, intellegite et erudimini, qui iudicatis terram; seruite domino in timore.

53 Augustine, Epistulae 93.4 (CSEL 34.2, pp. 456-6I). $\quad{ }^{54}$ Ibid., 93.3.9 (CSEL 34.2, p. 453).
} 
Indeed, if the circumcelliones simply stop their violence out of fear of imperial punishment by the state, the normal process of persuasion can start again:

[W] ho is so mad to deny that one is obliged to come to their help [that is, of well-intentioned Donatists] by imperial orders, so that they be freed from such an evil, whilst the others [the circumcelliones], whom they fear now, are forced to fear and by this very fear they [the circumcelliones] are themselves corrected, or, at least, when they feign to be corrected, keep away from the corrected [the well-intentioned Donatists], by whom they were feared before? ${ }^{55}$

Throughout his justification of coercion by the state, Augustine keeps coming back to the general framework of thought, according to which a community is oriented towards the good and its leader has the duty to take care that the community remains so. This implies an educative process that is primarily (logically and temporally) one of argument and persuasion, for only reasoned acceptance of the truth is possible. Coercion is possible within the community, ${ }^{56}$ yet can only function as a means to remove obstacles to the reasoned acceptance of the truth: coercion itself never can produce a true conversion. In his writings, Augustine identifies various actors of correctio (correction) and correptio (reprimand), such as God himself (who corrected Paul on the road to Damascus), the Church or, as in this case, the state. ${ }^{57}$ God obviously is a force for the good, and the Church, as long as it is orthodox, also aims at the good. The state, by contrast, is not by definition a force for the good: as Augustine's reference to Psalm 2 indicates, there was a time when rulers were not Christians. Even when they have become Christians, the state does not simply become acceptable as a means to regulate the life of the Church. Indeed, the state remains a different community from the Church, with different leaders, a different history and a different purpose. This is most visible in Augustine's awareness that a state official disposes of a wider range of punishments than a bishop, including measures such as the death penalty that are objectionable from an ecclesiastical perspective. ${ }^{58}$ There is never a simple

\footnotetext{
55 Augustine, Epistulae I 85.3.13 (CSEL 57, p. I 2): quis est tam demens, qui neget istis debuisse per iussa imperialia subueniri, ut de tanto eruerentur malo, dum illi, quos timebant, timere coguntur et eodem timore aut etiam ipsi corriguntur aut certe, cum se correctos esse confingunt, correctis parcunt, a quibus antea timebantur? Cf. Epistulae I 85.4 (CSEL 57, pp. I3-17).

56 On the normality of forms of coercion in communities, see J. Hillner, 'Monks and Children: Corporal Punishment in Late Antiquity', European Review of History I6 (20I I) 773-91; Van Geest, 'Quid dicam de vindicando', 153 . On violence in general, J.-U. Krause, Gewalt und Kriminalität in der Spätantike (Munich, 20I4).

57 Van Bavel, 'Correctio' and 'Correptio'; Grossi, 'Correctio'. $\quad{ }^{58}$ Rist, Augustine, 243.
} 
identity between the two communities that would allow the state to interfere with the Church. The problem in appealing to state coercion, then, lies, in intellectual terms, in the fact that one has recourse to another community to resolve problems that are internal to one's own. As Augustine indicates, coercion by the state in Church matters can only be justified if the state laws are inspired by the truthful good. Yet acceptance of state authority remains, for Augustine, always conditional: 'Consider who commands, who is commanded, and what is commanded.' 59 Acceptance of coercion by the state is thus, by definition, provisional, for one can never be sure the state has the same good in mind as the Church.

Older scholarship has tended to emphasise the change in Augustine's position. The present analysis, which argues that Augustine remained true to a single framework of thought, does not necessarily conflict with such a view, as long as one is clear about what changes. It is wrong to think Augustine changed on the substance of his view: he did not shift from a 'tolerant' position to an 'intolerant' one. There is no change in the basic presuppositions of his position: there is no point, for example, when he believes that coercion can generate true belief. Coercion remains a secondary means to eliminate obstacles to a free acceptance of the truth. Rather, we see Augustine emphasising different elements within the framework, largely in function of the precise circumstances. Unsurprisingly, justification of state coercion occurs at a time when, in the Catholic perception, the conflict with the Donatists has become extremely violent.

Crucially, coercion itself is not the problem: what worried Augustine's interlocutors was coercion by the state in Church matters. We can now also understand better why the problem is articulated by Augustine so expressly in the context of the Donatist conflict and not concerning antipagan and anti-Jewish laws - measures that are, by modern scholarship, often lumped together. In the communal logic that underpins Late Antique reasoning, ${ }^{60}$ state laws against pagans and Jews do not intervene

59 Augustine, Epistulae I 85.2.8 (CSEL 57, p. 7); Sermones Dolbeau 3.I4-1 5 (p. 338 Dolbeau): videte quis iubebat, cui iubebat, quid iubebat.

6o There is a broader background to the espousal by the Church of the self-understanding of a philosophical community, which we can only sketch here. J. Rüpke, From Jupiter to Christ: On the History of Religion in the Roman Imperial Period (Oxford, 20I4), has argued that the nature of religion changes in the Roman empire and that it starts to relate to the entire breadth of human life. P. Athanassiadi and C. Macris, 'La philosophisation du religieux', in L. Bricault and C. Bonnet (eds.), Panthée: Religious Transformations in the Roman Empire (Leiden, 2013) 4I-84, have in turn highlighted the impact of philosophy on ancient religion under the empire (cf. P. Van Nuffelen, Rethinking the Gods: Philosophical Readings of Religion in the Post-Hellenistic Period [Cambridge, 20I I]). J. North, 'The Development of Religious Pluralism', in J. Lieu, J. North and T. Rajak (eds.), The Jews among Pagans and Christians (London, 1992) 174-93, has argued for a social 
in the Christian community. Obviously, if they provoke conversion, they have an effect on that community, and they may reflect the symbolic superiority of the Church among the various communities, but they regard communities that remain outside the Christian one. The Donatist conflict was, by contrast, a rift within the Christian community, to which the state was, by definition, alien.

\section{Conclusions}

Augustine has sometimes been depicted as letting the cat out of the sack and opening the door for future state coercion. ${ }^{6 \mathrm{I}}$ In fact, he has, in his typical way, explored issues that were common in his time, remaining within the bounds of the thought of his period. That thought was, in turn, tributary to earlier philosophical ideas. What his letters clearly show, however, is that the fault line around which the discourse on coercion clusters is not the mere fact of coercion, but rather its source and, from an ecclesiastical perspective, in particular the use of state coercion for intracommunal problems. That this would be the moot point becomes clear against the background of the communal logic, derived from classical philosophy, that underpinned the self-understanding of communities and of their leaders. As the crucial and recurring problem, it receives massive attention in our sources: much space in the late ancient Church histories is taken up by justifying or rejecting state interference. Unjustified coercion by the state is easily labelled persecution, a highly charged term in late ancient sources. ${ }^{62}$ In the end, Augustine does little more than extensively justify that he remains within the boundaries of what was morally acceptable in his age. Ordinary coercion by a bishop towards his flock is, by contrast, less visible in the sources. Unsurprisingly, a discourse generates visibility by imposing a meaning and a valuation on events. We cannot reconstruct the past if we are not fully aware of the fact that our sources

change in the make-up of imperial religions, which become more structured around new communities. J. Rüpke, Religious Deviance in the Roman World: Superstition or Individuality? (Cambridge, 2016), has linked this to the changing definition of religious deviance, which becomes more clearly articulated in later Antiquity. I have limited myself here to the perspective of intellectual history. For further reflection on how scholars have linked the rise of more structured religious communities with the development of the concept of religion itself, see Bendlin, this volume, pp. ooo-oo.

${ }^{61}$ M. Gaddis, 'There is no Crime for Those Who Have Christ': Religious Violence in the Christian Roman Empire (Berkeley, 2006) I33.

62 See P. Van Nuffelen, 'Religious Violence in Late Antiquity', in L. Fibinger, G. G. Fagan and M. Hudson (eds.), The Cambridge World History of Violence, vol. I (Cambridge, forthcoming). 
never merely reflect reality but construct and valuate it. ${ }^{63}$ In addition, the apparent similarity of the issue at stake with the origins of modern toleration (the problematic nature of state intervention in religious communities) has ensured continued attention in scholarship - indeed, given the importance of Patristic texts for arguments during the Reformation, it is not far off the mark to say that modern discussions of toleration, which circle around the role of the state, have late ancient roots.

If, then, Augustine, in a way, has set the terms for modern debates, modern presuppositions risk obscuring our analysis of late ancient ideas about coercion, as they do for the wider concepts of 'religion' and 'violence'. ${ }^{6}$ In this chapter, I have addressed one of these, namely the assumption that coercion and persuasion are mutually exclusive attitudes towards religious difference and that the former is an illicit and the latter an acceptable position. For us, coercion infringes on an individual's freedom, a cornerstone of a modern anthropology. Yet in Antiquity virtue, not freedom, was the highest aspiration of humans: a freedom that consists in not doing good is an evil. Moreover, the progress towards freedom was not an individual's road, but took place in dialogue with a master and a community. Crucially, the ultimate ends of one's life were the object of rational analysis, just as was discussion about things divine. If it has been said that in a modern state toleration is necessary for religious ideas because they cannot be debated rationally, ${ }^{65}$ in Late Antiquity, religion was a locus of reason. Awareness of such fundamentally different presuppositions about individual and society may help us to avoid studying late ancient coercion as just another instalment of the historically unchanging problem of 'toleration'.

${ }^{63}$ This platitude bears repeating, especially when one is dealing with a topic like toleration that is central to modern self-understanding. For its application to religious violence, see P. Van Nuffelen “"A Wise Madness": a Virtue-Based Model for Crowd Behaviour in Late Antiquity', in W. Mayer and C. L. de Wet (eds.), Reconceiving Religious Conflict: New Views from the Formative Centuries of Christianity (London, 2018) 234-58, and 'Religious Violence'.

${ }^{64}$ See n. 3 above. ${ }_{65}$ J. Rawls, A Theory of Justice (Oxford, I97I) 213. 